\title{
International adaptation of the hydrologic rational method: Floods study in the North Portugal Region
}

\author{
Adaptación internacional del método racional \\ hidrológico: Estudio de las inundaciones en la Região \\ do Norte de Portugal
}

VÁZQUEZ-RODRÍGUEZ, A. L.

Instituto Universitario de Xeoloxía Isidro Parga Pondal (IUX). A Coruña (Spain).

alexandreluis.vazquez@gmail.com

https://doi.org/10.17979/cadlaxe.2019.41.0.5810

enviado: 8/2/2019 aceptado 23/7/2019

\begin{abstract}
Floods have a big capacity of create great social and economic losses in a short time interval. Spain and other countries have this problem in their territories. These can have different origins, being the rivers overflowing the more common cause. There are different approaches of these phenomena studies, and the modified Témez rational method is the referenced one in Spain, which with the GIS and hydrological simulation programs can create the flooding areas cartography, key information in the floods hazard management. But, is this method only valid for Spain, or is it applicable to other countries? The answer is that its adaptation to other countries is possible, always that the releveant modifications are made.
\end{abstract}


In the Iberian Peninsula, Portugal is a country that has the flooding problem too. Because this country has a similar geological and geographical conditions to the western Spain, and the floods effects are similar in the Portuguese territories, the adaptation to this country it's relatively simple.

The aim of this work is the study of floods dynamics in Portugal, adaptating the modified Témez rational method. This method will be applied in the Âncora river, in North Portugal region fluvial system because the geological and geopraphical conditions are similar to the west of Spain ones.

Keywords: Floods, GIS, Hydrological Modelling, Hydrological Rational Method, Portugal

\section{Resumen}

Las inundaciones tienen una gran capacidad de crear grandes pérdidas sociales y económicas en un corto intervalo de tiempo. España y otros países tienen este problema en sus territorios. Estos pueden tener diferentes orígenes, siendo los ríos que desbordan la causa más común. Existen diferentes enfoques de estudio de estos fenómenos, y el método racional modificado de Témez es el referenciado en España, que con el SIG y los programas de simulación hidrológica puede crear la cartografía de las áreas inundables, información clave en la gestión del riesgo de inundaciones. Pero, ¿este método sólo es válido para España, o es aplicable a otros países? La respuesta es que su adaptación a otros países es posible, siempre que se realicen las modificaciones pertinentes.

En la Península Ibérica, Portugal es un país que también tiene el problema de las inundaciones. Debido a que este país tiene unas condiciones geológicas y geográficas similares a las del oeste de España, y los efectos de las inundaciones son similares en los territorios portugueses, la adaptación a este país es relativamente sencilla.

El objetivo de este trabajo es el estudio de la dinámica de las inundaciones en Portugal, adaptando el método racional modificado de Témez. Este método se aplicará en el río Âncora, en el sistema fluvial del norte de Portugal, ya que las condiciones geológicas y geográficas son similares a las del oeste de España. 
Palabras clave: Inundaciones, SIG, Modelización Hidrológica, Método Hidrológico Racional, Portugal

\section{INTRODUCTION}

A flood is the natural process which the water overflows its natural limts. The majority of the floods are related with the rainfall quantity and distribution of the area, the speed with which rainfall soaks the ground and the speed with which runoff from rainfall reaches the water sources (KELLER \& BLODGETT, 2007). All the rivers have different irregularities that lead to frequent small floods, uncommon big floods and few extraordinary floods (VÁZQUEZ-RODRÍGUEZ, 2015; 2017).

All territory that articulates in a antrophised fluvial space is a territory with floods risk. If a natural event does not affect human being, the risk would not be considered due to the exposed elements absence (OLCINA, 2006)"type":"book" \},"uris":[“http://www. mendeley.com/documents/?uuid=aa8e19673eac-4c8c-8081-bb6e47ac6007"]\}],"mende ley": \{ “formattedCitation":"(Olcina, 2006. There are different floods types, classified by their origin, being the more common:

- River floods: Caused when the river water flux overflows its banks (KELLER \& BLODGETT, 2007).

- Flash floods, or torrential floods: Caused when the water volume rise suddenly due to torrientally rainfall or to the sudden snow melting (KELLER \& BLODGETT, 2007).

- Coastal floods: Caused by higher than average high tide and worsened by heavy rainfall and onshore winds in land areas along the coast (THE NATIONAL SEVERE STORMS LABORATORY, 2016).
- Snow melting floods: Caused by the extra water supply originated by the spring snow (or glacier) melting (SINGH \& SINGH, 2001).

- Urban floods: Cause by the overcoming the capacity of the anthropic drainage systems in the urban areas (US FEDERATION EMERGENCY MANAGEMENT AGENCY (FEMA), 2016).

- Dam and Levee failure floods: caused by the construction of inadequate dams and levees or to a flood that exceeds the design protection level (FEMA, 2016).

In the Iberian Peninsula, there are frequent flood episodes, mainly caused by a big rainfall volume, overflowing river banks or drainage systems, or by a higher than average high tide in coastal settlements. The official institutions available data, the modified Témez Rational Method (Témez, 1987; Ferrer, 1992; Ministerio de Obras Públicas y Urbanismo (Spain) (MOPU), 2016), the official estimation method in Spain with the needed modifications to apply on Portugal, the geographical information systems ArcGIS and SAGAGIS (GIS) and HecRAS hydrological modeling software were used to adapt and apply the spanish method in the Portugal territory.

\section{STUDY AREA}

Portugal North Region (Região Norte in Portuguese) is a statistical region of Portugal comprising Viana do Castelo, Braga, Vila Real, Braganza and Porto districts plus part of Aveiro, Viseu and Guarda districts (Fig. 1). It's located between $42^{\circ} 12^{\prime} 10^{\prime \prime}$ $40^{\circ} 45^{\prime} 00^{\prime \prime} \mathrm{N}$ and $8^{\circ} 55^{\prime} 00^{\prime \prime}-6^{\circ} 10^{\prime} 00^{\prime \prime}$, in the northwest Iberian Peninsula. It has 21.278 $\mathrm{km}^{2}$ and an approximated population of 4.200.000 hab, more than a third part of the 
country total population, 10.309.573 hab (PORDATA, 2016).

The rational method has a basin size limitation; the watershed of the river can not be greater than $200 \mathrm{~km}^{2}$. In Spain this limitation was overcome by dividing the basins in sub-basins, enabling the use of the rational method in all the Spanish territory. Because of this limitation two basins were selected to the present work: A Miño river sub-basin, the one corresponding to the villages of Tui (Spain) and Valença do Minho (Portugal) (Fig. 2), with a size of $21 \mathrm{~km}^{2}$ and the Ancora river basin (Fig. 2), with a size of $128 \mathrm{~km}^{2}$, in the sector were Âncora village its located.

The characteristics of the geological materials where the settlements are located are important factors in the probability of floods in an area, because materials with lower permeability imply that the volume of runoff water on the surface will be greater, being more probable the foods in settlements located over impermeable materials. In the basins analysed the dominant geological materials are granitoids and conglomerates (Fig. 2). Granitoids are impermeable materials (Taylor \& Eggeton, 2001) as well as that of conglomerates depends on its composition and cementation (Boggs, 2009). Each geological material permeability has its own value in the rational method, derivated from the curve number method developed by the United States Department of Agriculture (1986). Other factors like the altitude and slope of the villages, and the urban percentage of them have its influence too. Higher areas will have less probability to experimentate a flood, the same happens in sections with high slope gradients. Meanwhile, urban areas will have a bigger probability because the urban materials of the city are impermeable. To alleviate this, when a village is being building, artificial drainage systems are built too, but they are not always enough,

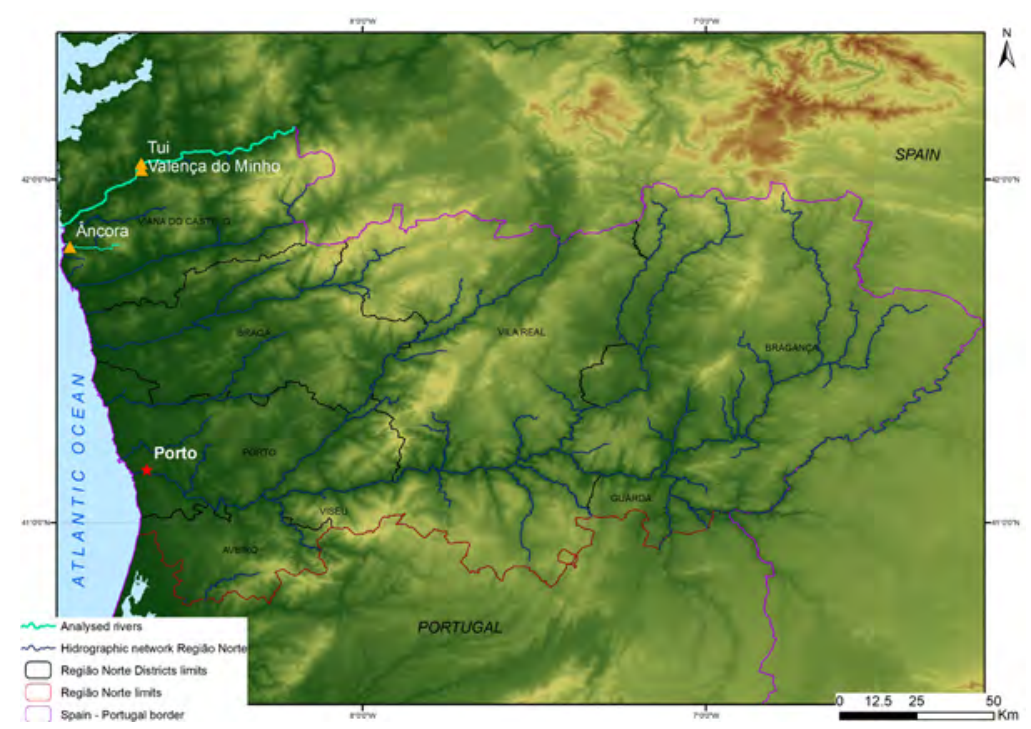

Fig. 1. Study area location. DEM from Copernicus Land Monitoring Service (European Union). 


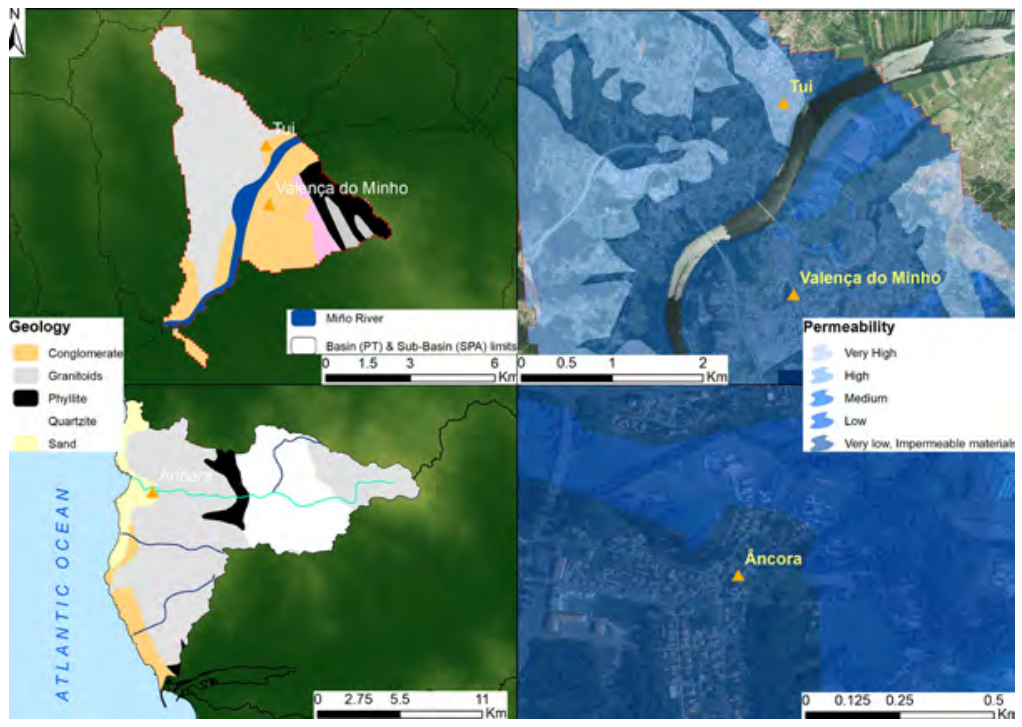

Fig. 2. Analysed basins materials and permeability. Geology and Permeabiliy shapefile from Europen Geology Data Infrastructure (EGDI). Tui aerial imagery from PNOA (IGN Spain), Âncora aerial imagery from Google Earth.

because they require a big capacity to evacuate large volumes of water and an constant maintenance (which is not always done).

\section{METHODOLOGY AND OBJECTIVES}

The objective of the current work its to adapt the modified Témez rational method in other countries, with which required data for the flood areas cartography are obtained. There are previous articles by the insitutions of some countries, like the the Brazilian one (Tucci \& Porto, 1999), the Oregon case (USA Oregon Geo-environmental Department, 2014), or the Australian one (Queensland Goverment, 2015), but they are few, either for lack of this type of studies or for the use of other methods to estimate the floods within its borders. The modified Témez rational method (Témez, 1987; Ferrer, 1992; MOPU, 2016) was applied because it's a hydrometeo- rological method that takes into account the main factors involved in the floods flows.

Every country has its own data source, and all the required one was compiled to apply this method in Portugal. The geological information was extracted from the European Geological Data Infrastructure (EGDI), the landuses from the European Copernicus Land Cover (CLC) 2018 version, the aerial imagery from the PNOA of the Instituto Geográfico Nacional (IGN, Spain) for the Tui - Valença case and from Google Earth for the Âncora case. Previous required data were calculated too: the basin number, the precipitations intensity or the Manning coefficient (Chow, 1959), among others (Table 1). The results will be the peak flow values (m3/s) of the Miño and Âncora rivers for different time intervals, denominated return periods. The standard reference periods are 25, 50 and 100 years, representing the 25 
years flood as common or frequent, the 50 years floods as uncommon or less frequent, and the 100 years flood as extraordinary or even less frequent but with a bigger range. These peak flows are the maximum flows produced by the rivers in a rise event of its usual level. Obtained the required peak flow values, these data were carried to HecRAS 5.0.3 hydrological modelling software, to simulate the floods in the study area. Later, the HecRAS results were carried over ArcGIS 10.1 GIS to create the flood areas cartography. During the process small errors derived from the processing were fixed. In both cases exists similar maps created by official institutions but this cartography presents some errors and they are not avaliable to work with them, only to examine them. 


\begin{tabular}{|c|c|c|}
\hline Calculated Variables & Formula & Variables \\
\hline $\begin{array}{l}\text { Rainfall treshold and } \\
\text { Corrected rainfall } \\
\text { treshold }\end{array}$ & $\begin{array}{c}P_{o}=\text { MOPU tables } \\
P_{o}^{\prime}=P_{o} \cdot b\end{array}$ & $\begin{array}{c}P_{O}(\mathrm{~mm})=\text { Rainfall treshold } \\
P_{O}^{\prime}(\mathrm{mm})=\text { Corrected rainfall treshold } \\
b=\text { Rainfall treshold correction coefficient. MOPU tables }\end{array}$ \\
\hline $\begin{array}{l}\text { Basin Time of } \\
\text { concentration }\end{array}$ & $T c=0,3 \cdot L c^{0.76} \cdot J c^{-0.19}$ & $\begin{array}{c}\text { Tc (hours) = Basin Time of concentration } \\
\qquad \mathrm{Lc}(\mathrm{m})=\text { Channel length } \\
J c(\mathrm{~m} / \mathrm{m})=\text { Channel slope }\end{array}$ \\
\hline Area reduction factor & $\begin{array}{c}\text { Si } \mathrm{S}<1 \mathrm{~km}^{2} \quad \Rightarrow \quad K_{A}=1 \\
\text { Si } \mathrm{S} \geq 1 \mathrm{~km}^{2} \\
K_{A}=1-\frac{\log S}{15}\end{array}$ & $\begin{array}{c}K_{A}=\text { Area reduction factor } \\
\quad S\left(\mathrm{Km}^{2}\right)=\text { Basin area }\end{array}$ \\
\hline Runoff coefficient & $C=\left(P_{D}^{\prime}-P_{O}^{\prime}\right) \cdot \frac{P_{D}^{\prime}+23 \cdot P_{O}^{\prime}}{\left(P^{\prime}+11 \cdot P^{\prime}\right)^{2}}$ & $\begin{array}{c}C=\text { Runoff coefficient } \\
P_{D}^{\prime}(\mathrm{mm})=\text { Corrected daily rainfall for a duration } \mathrm{D} \\
(\text { equivalent to a return period } \mathrm{T}) \\
P_{O}^{\prime}(\mathrm{mm})=\text { Corrected rainfall treshold }\end{array}$ \\
\hline Intensity of rainfall & $I(T, t)=I_{D} \cdot \mathrm{F}_{\mathrm{int}}$ & $\begin{array}{c}I(T, t)(\mathrm{mm} / \mathrm{h})=\text { Intensity of rainfall corresponding to a } \\
\text { return period } \mathrm{T} \text { and to a rainfall duration } \mathrm{t} \\
I_{D}(\mathrm{~mm} / \mathrm{h})=\text { Average daily corrected rainfall intensity } \\
\text { corresponding to a return period } \mathrm{T} \\
\mathrm{F}_{\text {int }}=\text { Intensity factor }\end{array}$ \\
\hline $\begin{array}{l}\text { Average daily corrected } \\
\text { rainfall intensity }\end{array}$ & $I_{D}=\frac{P_{D}}{24} \cdot \mathrm{K}_{\mathrm{A}}$ & $\begin{array}{l}\text { Id }(\mathrm{mm} / \mathrm{h})=\text { Average daily corrected rainfall intensity } \\
\text { Pd }(\mathrm{mm})=\text { Daily precipitation corresponding to a return } \\
\text { period } \mathrm{T} \\
\mathrm{K}_{\mathrm{A}}=\text { Rainfall reducing factor by the basin area }\end{array}$ \\
\hline Intensity factor & $\begin{array}{c}\text { Fint }=\text { máx }(\mathrm{Fa}, \mathrm{Fb}) \\
\begin{array}{c}F_{a}=\left(\frac{I_{1}}{I_{d}}\right)^{3,5287-2,5287 . T c^{0.1}} \\
F_{b}=k_{b} \frac{I_{I D F}(T, T c)}{I_{I D F}(T, 24)}\end{array}\end{array}$ & $\begin{array}{c}\text { Fint }=\text { Intensity factor } \\
\text { Fa = Factor obtained from the torrentiality index (I1 / Id }) \text {, } \\
\text { in the tables of the MOPU } \\
\mathrm{Fb}=\text { Factor obtained from the IDF curves of a nearby } \\
\text { pluvigraph }\end{array}$ \\
\hline & & $\begin{array}{l}\text { IDF }(\mathrm{T}, \mathrm{tc})(\mathrm{mm} / \mathrm{h})=\text { Rainfall intensity corresponding to } \\
\text { the return period } \mathrm{T} \text { and the basin time of concentration } \\
\mathrm{Tc} \text {, obtained through the IDF curves of the nearby } \\
\text { pluviograph } \\
\text { IDF ( } \mathrm{T}, 24)(\mathrm{mm} / \mathrm{h})=\text { Rainfall intensity corresponding to } \\
\text { the return period } \mathrm{T} \text { and to a rainfall time equal to } 24 \text { hours } \\
\text { ( } \mathrm{T}=24 \mathrm{~h}) \\
\mathrm{kb} \text { (dimensionless) = Factor that takes into account the } \\
\text { relationship between the maximum annual rainfall } \\
\text { intensity in a } 24 \text {-hour period and the maximum daily } \\
\text { annual rainfall intensity. In the absence of a specific } \\
\text { calculation can be used kb }=1,13\end{array}$ \\
\hline Peak flow & $\begin{aligned} Q t & =\frac{I(T, t c) \cdot C \cdot S}{3.6} * K \mathrm{t} \\
K_{t} & =1+\frac{t^{1,25}}{t_{c}^{1,25}+14}\end{aligned}$ & $\begin{array}{c}Q t\left(\mathrm{~m}^{3} / \mathrm{s}\right)=\text { Peak flow } \\
C=\text { Runoff coefficient } \\
I=\text { Rainfall intensity corresponding to the analyzed return } \\
\text { period } \\
S\left(\mathrm{~km}^{\prime}\right)^{\prime}=\text { Basin area } \\
K_{t}=\text { Uniformity correction coefficient }\end{array}$ \\
\hline
\end{tabular}

Table 1. Rational method variables and formulas. Source: Modified Rational Method (Témez, 1987, Ferrer, 1992, MOPU, 2016). 


\section{RESULTS}

Rational method was applied over 2 different sectors. Peak flows values were estimated for the Miño and Âncora rivers (Table 2). With these values the flood areas cartography was made. When it comes to ur- ban areas, with a big concentration of buildings, the exposed elements number will be greater than in an despopulated settlement or one with less built elements. The effects are not the same if the flood affects a large quantity of buildings that it affects a ranch for example.

PEAK FLOWS

\begin{tabular}{|l|c|c|c|}
\hline Basin & T25 & T50 & T100 \\
\hline Tui - Valença do Minho & 29.1 & 37.7 & 48.03 \\
\hline Âncora & 14 & 20.27 & 28.24 \\
\hline
\end{tabular}

Table 2. Peak flows for the reference return periods of Miño and Âncora rivers.

In the Miño river case, the cartography related to a 100 years' flood was analysed because of the minimum effect of the flood in the other return periods (Fig. 3). This differs in the Âncora river case, were the maps corresponding to the 3 return periods were anlalysed because the effects on the 3 time intervals is important (Fig. 3).

According to the models both sectors would have problems, in a differente degree, generation economic losses to its inhabitants. The possiblility of human losses it's present too. In the Tui - Valença case the effects of natural floods are few, in the Portuguese part just some sections of the farms located on the Miño river bank would suffer floods, which would mean economic losses for their owners. In the other bank, Tui port facilities and riverwalk will be flooded generating economic losses to the government and the population. In this case even the existence of human fatalities is possible because riverwalk can be transited.

In the Âncora case, the effects are larger. Even in the 25 years return period situation, some farms plus four urbanizared areas are affected by floods. In the 50 and 100 years return periods the floods are a bit bigger, but affects the same elements. This means economic losses for the habitants and a bigger probability of human losses, because people spend time in their residences. A 25 years return period flood means that the floods in that area are frequent and they can be a recurrent problem in Âncora if no measures are applied.

With these maps of the flood areas, priority intervention areas can be determinated, being a key fact in the establishment of prevention and mitigation measures and in the flood prevention, or evacuation related plans. As seen the Témez rational method seems applicable in the Portuguese territory. 


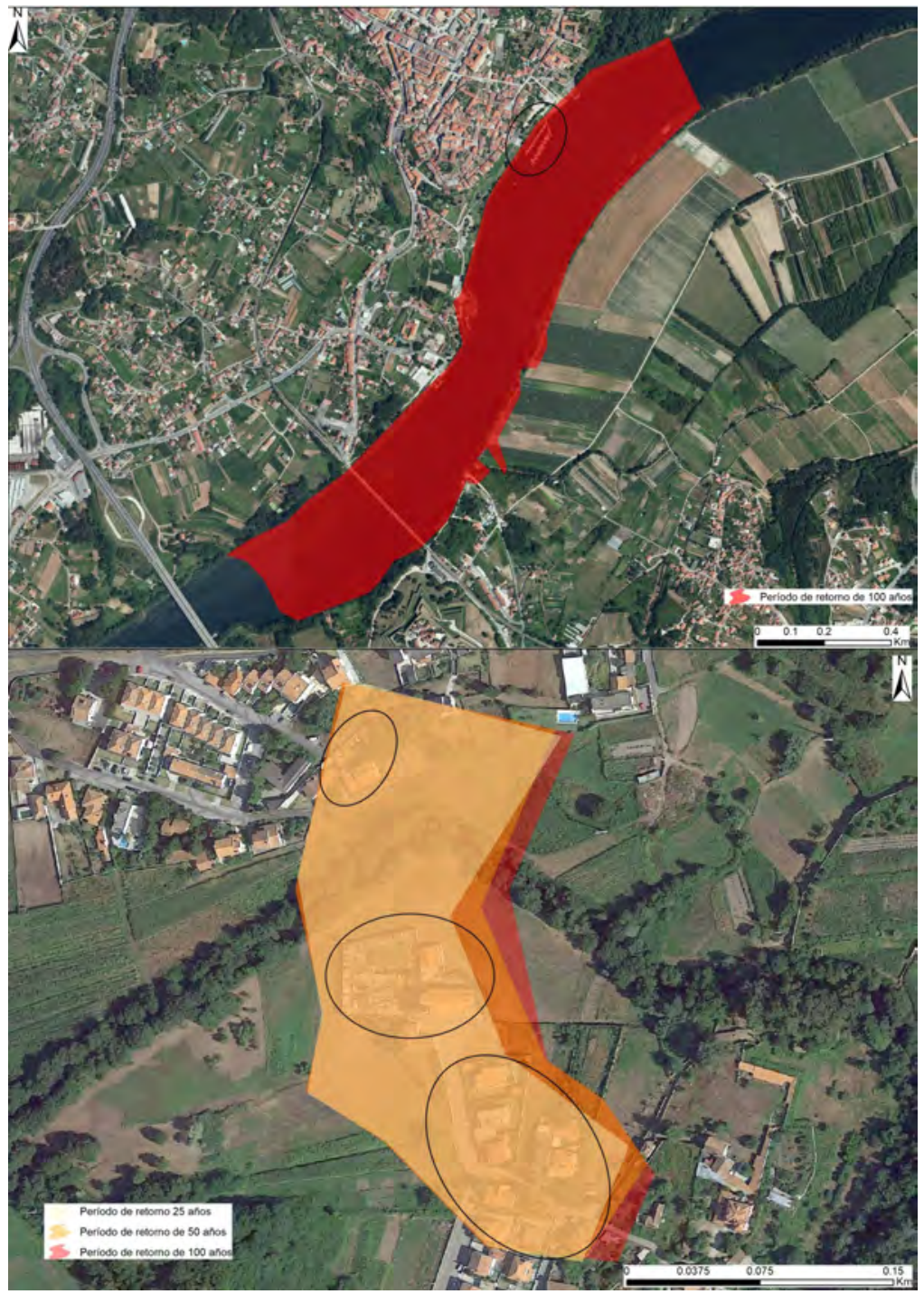

Fig. 3. Flood areas associated to Minho river (top) and to Âncora river (bottom) for 25, 50 and 100 years return periods. Tui aerial imagery from PNOA (IGN Spain), Âncora aerial imagery from Google Earth.

\section{DISCUSSION}

Creating the flood areas cartography, it should be aware that the result it's an estimation of these, a model that have to be fixed and contrasted to make it as real as possible. Models depend of the avaliabilty of the required data, the more the data, the more correct the models will be. In the Spain case all the required data is accessible 
in diferrent institutions while in the case of Portugal part of the information have not free acces. Whatever, in this case, part of the data can be obtained from the Spanish nearest sources, because of its location and its similar geographic, hydrological and geological characteristics with the west of Spain. For the Âncora floods map some Spanish data were used to complete the required variables for the cartography. The available data are those that condition the precision of the models in the Témez rational method. The more data, the better results.

In the Portuguese case, some areas have a flood areas map created by using other methods (sqrtmax, among others) and only in the biggest rivers, In the Ancora river area there is not cartography related. With the required data obtained from the mentioned sources, the Témez rational method was applied to the study areas and the floods areas maps were created. The proximity of this river basin to Spain borders facilitates the use of this rational method. In further areas, like Lisboa for example, more extrapolation and more data modification its required, being the resultant model more an approximation than the actual situation. Then, is the Spanish rational method applicable on Portugal territory? At least in the continental Portugal yes, in the islands or in other countries it will be conditioned it there are the necessary data to apply it, if not then another method has to be applied, or new data would have to be obtained by the responsible state institutions.

\section{CONCLUSIONS}

To the intial question: Is Témez rational method adaptable to other countries? The answer is yes, always that the necessary ma- terial exists to apply it. Not all the countries have the same information about geology, geomorphology or clima, among others, and neither all the countries have this information on free acces. The rational method is focused to countries, like Spain, that have a big quantity of data available to use it. All the years, different parts of the planet have the floods problem, being the flood areas cartography a key tool to use in the flood risk prevention, management and mitigation. The efficiency of evacuation, or civil protection plans partially depends of these materials. Other countries have this information for the same motive, but the public acces its scarce, difficulting every related researchs. This limited avaliabily can be harmful for the population settled on flood areas, because they are potentially vulnerable elementes to this hazard, and if they don't have the information they probably don't know how to do on an emergency case, rising the probabily of human losses when an event happens.

In the Portuguese case exists related information to the flood areas in some country sections, but not all the materials are available for further researchs. Applying the Témez rational method had some difficulties derivated from the lack of data. However, being a bordering country facilitates the use of Spanish data to cover this lack, at least on the continental part, but, since the data is not exact, the elaborated model starts with a margin of error. As an approximation of the international adaptation of this method, the results had been positives, but with the availability of all of the data the model will be better.

In Portugal the method application was successful because of geopraphic proximity and the geologic and geomorphologic 
similar to the west of Spain conditions, but in other countries, is it applicable? In other territories the applicability of the method will be achievable, depending of the avaliable data, or it there are the sources to create the required ones, since each territory has its own physical characteristics, and proximity does not always imply similar characteristics. How to apply it and the time required to do it would depend of the data situation of the area that the researcher wants to analyse.

\section{BIBLIOGRAPHY}

BOGGS, S. (2009). Petrology of Sedimentary Rocks. Cambridge University Press. Cambridge

CHOW, V. TE. (1959). Hidráulica de canales abiertos. McGraw-Hill, Bogotá.

COPERNICUS LAND MONITORING SERVICE. Corine Land Cover 2018. Retrieved from https://land.copernicus. eu/pan-european/corine-land-cover

EUROPEAN GEOLOGICAL DATA INFRASTRUCTURE (EGDI). Spain and Portugal geology. Retrieved from www. europe-geology.eu

FERRER, J. (1992). Análsis estadístico de caudales de avenida. Centro de Estudios y Experimentación (CEDEX), Madrid

INSTITUTO GEOGRÁFICO NACIONAL (IGN) (Spain). Plan Nacional de Ortografía Aérea (PNOA). Retreived from www.ign.es

KELLER, E. A., \& BLODGETT, R. H. (2007). Riesgos Naturales. Procesos de la Tierra como riesgos, desastres y catástrofes. Pearson Educación, Madrid

MINISTERIO DE OBRAS PÚBLICAS Y URBANISMO (Spain). Gobierno de España. Orden FOM/298/2016, de 15 de febrero, por la que se aprueba la norma
5.2 - IC drenaje superficial de la Instrucción de Carreteras., Boletín Oficial del Estado § (2016). https://doi.org/BOEA-2012-5403

OLCINA, J. (2006). ¿Riesgos naturales?I. Sequías e Inundaciones. Ed. Davinci, Barcelona.

OREGON (USA) GEO-ENVIRONMENTAL DEPARTMENT. (2014). Appendix F - Rational Method. In Hydraulics Manual (pp. 7-F-1-7-F-14). Salem: Oregon (USA) Geo-environmental Department.

PORDATA. (2016). Base de Dados Portugal Contemporáneo. Retrieved from www.pordata.pt

QUEENSLAND GOVERMENT (AUSTRALIA) (2015). The Empirical version of the Rational Method. In Soil Conservation Guidelines for Queensland (pp. 1-18). Queensland Goverment (Australia), Brisbane.

SINGH, P., \& SINGH, V. P. (2001). Snow and glacier hydrology. Springer, Amsterdam.

TAYLOR, G., \& EGGETON, R. (2001). Regolith Geology and Geomorphology. Wiley, New York.

TÉMEZ, J. R. (1987). Cálculo hidrometeorológico de Caudales Máximos en Pequeñas Cuencas Naturales. Secretaría General Técnica. M.O.P.U., Madrid.

THE NATIONAL SEVERE STORMS LABORATORY (2016). Severe Weather 101 - Floods. Retrieved from https:// www.nssl.noaa.gov/education/svrwx101/ floods/types/

TUCCI, C. E. M., \& PORTO, R. L. (1999). Storm hydrology and urban drainage. In Curso Gestão do Território (pp. 77108). Ministerio Público Federal (Brazil). Brasilia. 
UNITED STATES DEPARTMENT OF AGRICULTURE (1986). Urban Hydrology for Small Watersheds. American Society of Civil Engineers, New York, US FEDERATION EMERGENCY MANAGEMENT AGENCY (2016). Chapter 2 Types of Floods and Floodplains. Retrieved from https://training.fema. gov/hiedu/docs/fmc/chapter 2 - types of floods and floodplains.pdf
VÁZQUEZ-RODRÍGUEZ, A. L. (2015). SIG y realidad: Inundaciones en As Pontes de García Rodríguez (A Coruña). Sémata: Ciencias Sociais e Humanidades, 27, 69-94.

VÁZQUEZ-RODRÍGUEZ, A. L. (2017). Inundaciones en el noroeste de la Península Ibérica: El caso de Pontedeume (A Coruña). Cátedra. Revista Eumesa de Estudios, 24, 217-232. 